\title{
Ragam Sulukan Wayang Kulit Purwa Gaya Yogyakarta: Studi Kasus Timbul Hadiprayitno, Hadi Sugito, dan Suparman
}

\author{
Sudarko $^{1}$ \\ Jurusan Pedalangan, Fakultas Seni Pertunjukan, Institut Seni Indonesia Surakarta
}

\begin{abstract}
ABSTRAK
Penelitian ini bertujuan untuk mencari penjelasan tentang ragam sulukan wayang kulit purwa gaya Yogyakarta versi Timbul Hadi Prayitno, Hadi Sugito, dan Suparman. Penjelasan itu didapat dengan jalan mencari persamaan dan perbedaan sulukan tiga dalang itu. dalam mencari persamaan dan perbedaan sulukan tiga dalang tersebut. Dalam mencari sebab-sebab terjadinya perbedaan sulukan digunakan landasan pemikiran Koentjaraningrat mengatakan bahwa segala bentuk perubahan yang terjadi dalam tata kehidupan masyarakat di antaranya disebabkan oleh tiga faktor pokok yakni: (1) ketidakpuasan terhadap hasil yang telah ada, (2) kemampuan di dalam bidangnya, dan (3) keinginan mendapatkan imbalan. Berdasarkan penelitian dapat disimpulkan bahwa persamaan sulukan tiga dalang terletak pada pathet, jenis, fungsi, hubungan cakepan dengan lagu, hubungan gendhing dengan sulukan. Sementara itu perbedaan sulukan terletak pada: (1) jenis lagon, suluk, dan kawin terletak pada wilet. (2) Jenis ada-ada yakni perbedaan pada wilet dan cakepan dan letak pada lagu pokok.
\end{abstract}

Kata kunci: ragam, sulukan, Yogyakarta.

\section{ABSTRACT}

The Various Mood Song of Yogyakarta Shadow Puppet Theater: A Case Study on Timbul Hadiprayitno, Hadi Sugito, dan Suparman's Work. This paper is intended to look for the explanations about the various kinds of puppet sulukan (mood song) in Yogyakarta style especially sulukan of Timbul Hadiprayitno, Hadi Sugito, and Suparman. The explanation was obtained by seeking similarities and differences of the three puppeteer's sulukan. In order to search for similarities and differences of sulukan, the comparative approach was used. Moreover, in searching for the causes of differences of sulukan, the theoritical framework by Koentjaraningrat was used. It says that any changes happened in the governance of community life of which they are caused by three main factors, namely: (1) dissatisfaction to the existing results, (2) the capabilities in one's field, and (3) the desire to get rewards. The similarities to the three puppeteers' sulukan lie on pathet, type, function, cakepan relationship with the song, and the relationship of gendhing with sulukan. Meanwhile, the differences of the three puppeteer's sulukan are on: (1) the type of lagon, suluk, and kawin which lies in wilet. (2) the type of ada-ada, namely the difference lies in wilet and cakepan and the difference lies in the basic song, wilet, and cakepan.

Keywords: mood song, pupputry, wayang

\section{Pendahuluan}

Pedalangan gaya Yogyakarta mempunyai dua ragam gaya pedalangan yaitu ragam gaya Keraton Kasultanan yang disebut juga Habirandha, dan ragam gaya kerakyatan (desa). Ragam habirandha muncul karena pengaruh sekolah dalang Habirandha (Hambiwarakaké Rancangan Andhalang) yang didirikan tahun 1925 atas perintah Sultan Hamengku Buwana VIII. Pedalangan ragam gaya Habirandha di Yogyakarta tidak didukung oleh dalang-dalang yang ada di desa. Ragam gaya pedalangan ini hanya didukung oleh dalang-dalang keraton (kota). Dalang-dalang di desa masih tetap menggunakan gayanya sendirisendiri yakni warisan dari orang tuanya. Hal ini dapat dilihat dari dalang-dalang yang pentas di desa-desa, jarang atau bahkan tidak ada yang menggunakan ragam gaya Habirandha. Banyak terjadi dalang-dalang lulusan Habirandha, kalau mendalang malah menggunakan ragam gaya di luar keraton dengan jalan meniru dalang-dalang terkenal seperti Timbul Hadiprayitno, Hadi Sugito, dan Suparman. Tiga dalang itu menjadi panutan bagi dalang muda pada zamannya, karena masing-masing mempunyai ciri khas pedalangannya sendiri. Ciri khas yang sangat menonjol dari tiga dalang itu terutama pada sulukan. Adanya ciri khas sulukan dari masingmasing dalang inilah yang menjadi alasan penulis untuk mengkaji sulukan.

Tulisan ini akan dibatasi pada sulukan dari tiga dalang yakni Timbul Hadiprayitno, Hadi

1 Alamat korespondensi: Prodi Pedalangan ISI Surakarta. Jalan Ki Hajar Dewantara, Surakarta. E-mail: sudarko_isi@gmail. com. 
Sugito, dan Suparman. Pemilihan tiga dalang itu didasarkan atas pertimbangan sebagai berikut: (1) Tiga dalang itu masing-masing mempunyai ciri khas di dalam sulukan. (2) Tiga dalang itu merupakan dalang tenar di Yogyakarta. (3) Tiga dalang itu masing-masing mempunyai penggemar dan pengikut sehingga menjadi panutan bagi dalang muda. Pertanyaan yang diajukan adalah (1) Bagaimana persamaan dan perbedaan sulukan dari tiga dalang tersebut? (2) Mengapa sulukan tiga dalang itu berbeda?

Upaya membandingkan sulukan Timbul Hadiprayitno, Hadi Sugito, dan Suparman akan dilakukan dengan pendekatan komparatif dengan cara menunjukkan persamaan dan perbedaan antara dua obyek atau lebih yang menggunakan dasar-dasar tertentu. Dasar mengadakan perbandingan adalah menempatkan sesuatu yang belum diketahui atau belum dikenal dalam rangka suatu hal atau barang yang sudah dikenal oleh pembaca atau pendengar. Membandingkan kedua hal itu berarti menempatkan obyek garapan perbandingan untuk mengetahui persamaan dan perbedaan (Gorys Keraf, 1982: 16).

Dalam mencari persamaan dan perbedaan sulukan Timbul Hadiprayitno, Hadi Sugito, dan Suparman dilakukan dengan cara membandingkan hal-hal yang sejenis di antaranya tentang: pathet, jenis, fungsi, hubungan cakepan (syair) dengan lagu, dan hubungan gendhing dengan sulukan. Konsep yang digunakan untuk menelusuri konteks sosial budaya yang melatarbelakangi adanya perbedaan sulukan tiga dalang sebagaimana yang dikemukakan oleh Koentjaraningrat adalah bahwa segala bentuk perubahan yang terjadi dalam tata kehidupan masyarakat di antaranya disebabkan oleh tiga faktor yakni: (1) ketidakpuasan terhadap hasil yang telah ada, (2) kemampuan dalam bidangnya, dan (3) keinginan mendapatkan imbalan.

Tiga dalang tersebut masing-masing berusaha memberikan sumbangan berupa sulukan. Hal ini akan dicoba didekati dengan melalui pemikiran Maurice Duverger (1981:356) yang mengatakan bahwa setiap generasi tidak akan puas dengan hanya mewariskan pusaka, dalam hal ini seni yang diterimanya dari masa lalu, tetapi akan berusaha untuk membuat sumbangannya sendiri.

\section{Suluk dalam Pertunjukan Wayang}

Ada beberapa pendapat yang memberi arti kata suluk. Sangkana Tjiptowardojo menjelaskan bahwa sulukan berasal dari kata suluk mendapat akhiran an yang berarti lampah. Sedangkan sulukan artinya suatu istilah di dalam pedalangan yang terdiri atas lelagoning dalang. Soepomo Poedjosoedarmo (1986: 127) juga menerangkan bahwa suluk adalah bentuk syair yang ditembangkan oleh dalang dengan diiringi beberapa alat musik gamelan, yakni gender, rebab, suling, dan gong.

Menurut Bambang Murtiyoso (1983: 17) sulukan adalah golongan atau jenis lagu vokal yang biasanya disuarakan oleh dalang untuk membantu memberikan efek suasana tertentu di dalam pakeliran. Poerwadarminta (1951: 571) mengatakan bahwa suluk berarti (1) tetembangan,

(2) kekidunganing dalang arep nyritakaké (ngocapaké) wayang, (3) laguning tembang sing ngemot piwulang (ngelmu) gaib.

Sangkana Tjiptowardojo mendefinisikan suluk sebagai berikut.

"Sulukan inggih punika sedaya lelagoning dhalang ingkang awujud: lagon, kawin, ada-ada, sendhon, lan sapanunggilanipun, ingkang minangka rerangkèning pakeliran, ingkang dipun tindkaken ing sasuwuking gangsa utawi ing salebeting pocapan kanggé ngisi raos jumbuhipun lan kawontenan, sarta kanggé ngombangi ungeling gangsa lan sapiturutipun. Ingkang punika lajeng kalimrah dipun wastani suluking dhalang." ("Sulukan adalah semua nyanyian dalang yang berujud lagon, kawin, ada-ada, sendhon, kombangan, dan sebagainya, yang penggunaannya merupakan kelengkapan pakeliran, yang dilakukan sesudah suara gamelan selesai atau di dalam narasi untuk membentuk suasana, serta untuk ngombangi suara gamelan dan sebagainya. Hal itu biasanya disebut suluking dhalang).

Dalam tulisan ini suluk dalam pakeliran wayang kulit purwa diartikan sebagai nyanyian dalang yang diiringi oleh beberapa ricikan gamelan dan atau suara kotak yang dipukul dengan cempala untuk menimbulkan dan memantapkan suasana dalam pakeliran. Pakeliran yang dimaksud adalah suatu bentuk seni pertunjukan yang menggarap cerita dengan boneka-boneka wayang sebagai pengganti tokoh-tokohnya, sedang gerak beserta 
percakapannya dilakukan oleh dalang dengan dukungan karawitan sebagai iringan (Murtiyoso, 1982: 5). Pakeliran gaya Yogyakarta adalah pakeliran wayang kulit purwa yang mempunyai ciri-ciri tertentu dan hidup di daerah budaya Yogyakarta.

Berdasarkan uraian di depan, yang dimaksud dengan ragam sulukan wayang kulit purwa gaya Yogyakarta adalah bermacam-macam nyanyian dalang yang diiringi oleh beberapa ricikan gamelan dan atau suara kotak yang dipukul dengan cempala untuk menimbulkan, memantapkan suasana di dalam pergelaran atau pertunjukan yang pelakunya dibuat dari kulit dan ceritanya mengambil dari Mahabarata, Ramayana, dan Arjunasasrabahu, sedangkan gerak dan percakapan dilakukan oleh dalang serta dengan dukungan karawitan sebagai iringan yang mempunyai ciri-ciri tertentu dan hidup di daerah budaya Yogyakarta.

\section{Persamaan dan Perbedaan Sulukan Timbul Hadiprayitno, Hadi Sugito, dan Suparman}

\section{Persamaan}

Sulukan Timbul Hadiprayitno, Hadi Sugito, dan Suparman mempunyai persamaan dalam hal pathet, jenis, fungsi, hubungan cakepan (syair) dengan lagu, dan hubungan gendhing dengan sulukan.

\section{Pathet}

Sulukan wayang kulit purwa gaya Yogyakarta versi Timbul Hadiprayitno, Hadi Sugito, dan Suparman terdiri atas tiga pathet yakni pathet nem, sanga, dan manyura. Adapun yang dimaksud pathet adalah pembagian waktu berdasarkan garap iringan yang terdiri atas tiga bagian (pathet nem, sanga, dan manyura) (Sudarko, 1994: 54).

\section{Jenis sulukan}

Menurut jenisnya, sulukan wayang kulit purwa gaya Yogyakarta terdiri atas empat jenis yakni: lagon, suluk, kawin, dan ada-ada. Lagon adalah nyanyian dalang yang diiringi oleh beberapa ricikan gamelan seperti rebab, gender, gambang, suling, dan gong. Suluk adalah nyanyian dalang yang diikuti oleh ricikan rebab, gender, gambang, dan gong. Kawin adalah nyanyian dalang yang diiringi ricikan gender, kempul, dan gong, serta diikuti dhodhogan kotak mbanyu tumetes. Adapun ada-ada adalah nyanyian dalang yang diikuti ricikan gamelan gender dan diikuti oleh dhodhogan kotak yang dipukul dengan cempala.

\section{Fungsi sulukan}

Sulukan di dalam pakeliran gaya Yogyakarta mempunyai dua fungsi yakni: fungsi struktural dan fungsi estetis. Fungsi struktural berkaitan dengan sulukan itu digunakan. Adapun fungsi struktural itu adalah sebagai berikut: (a) Lagon Nem Wetah digunakan di dalam jejer pertama setelah gendhing suwuk (selesai). (b) Lagon Nem Jugag, digunakan di dalam jejer pertama sebagai pengantar untuk mengalihkan pembicaraan dari bahasa yang selalu sama (Jawa: Bagongan) kepada inti pembicaraan. (c) Lagon Sanga Wetah digunakan menjelang perubahan pathet dari Pathet Nem ke Pathet Sanga yang di dalam kalangan pedalangan sering disebut petunjuk. Selain itu dapat pula digunakan pada adegan pendhitan di dalam Pathet Sanga, atau pada adegan satria di tengah hutan. (d) Lagon Sanga Jugag, dapat pula digunakan seperti pada Lagon Sanga Wetah kalau waktu telah mendesak. (e) Lagon Manyura Wetah, digunakan menjelang perubahan pathet dari Pathet Sanga ke Pathet Manyura. Selain itu dapat juga digunakan setelah gendhing suwuk di dalam adegan Pathet Manyura. (f) Lagon Manyura Jugag, dapat digunakan seperti pada Lagon Manyura Wetah, kalau waktu telah mendesak. (g) Suluk Plencung Wetah digunakan menjelang jejer ke dua. (h) Suluk Plencung Jugag, digunakan kalau di dalam jejer pertama ada tamu, yakni setelah gendhing suwuk. Selain itu juga digunakan dalam jejer ke dua (bukan raja raksasa) setelah gendhing suwuk. (i) Suluk Galong, digunakan pada jejer terakhir setelah gendhing suwuk. (j) Kawin Girisa, digunakan pada jejer pertama, selain Negara Astina yakni setelah Lagon Nem Wetah selesai. (k) Kawin Sikarini, digunakan pada jejer pertama Negara Astina yakni setelah Lagon Nem Wetah selesai. (l) Ada-ada Nem Wetah, Jugag dan Cekak, digunakan pada wayang perang dalam Pathet Nem. (m) Ada-ada Sanga Wetah, Jugag dan Cekak digunakan pada wayang perang dalam Pathet Sanga. (n) Ada-ada Manyura Wetah, Jugag dan Cekak digunakan pada wayang perang pada Pathet Manyura. (p) Ada-ada Galong, digunakan pada wayang perang menjelang akhir pertunjukan. 
Fungsi estetis, yakni sulukan berfungsi sebagai pemantap dan membuat serta mendukung suasana supaya pakeliran terasa lebih mantap dan lebih hidup. Adapun fungsi estetis itu adalah sebagai berikut: (a) Memantapkan keadaan jiwa, umpama keadaan suka menjadi lebih suka, digunakan sulukan lagon wetah. Keadaan marah menjadi lebih marah, dan suasana tegang menjadi lebih tegang digunakan sulukan ada-ada. (b) Membuat suasana, umpama membuat suasana marah menjadi tidak marah, membuat suasana sedih menjadi suasana suka, digunakan suluk lagon jugag. Membuat suasana lego, lerem, dan udhar, digunakan lagon jugag. Membuat suasana suka, digunakan sulukan lagon wetah atau jugag. Membuat suasana sedih, tangisan, trenyuh dan kasihan, digunakan sulukan suluk tlutur. Membuat suasana prenes, digunakan sulukan lagon wetah. Membuat suasana sereng, tegang dan marah, digunakan sulukan ada-ada. Membuat suasana émeng, digunakan sulukan lagon jugag. Membuat suasana regu, digunakan sulukan lagon nem wetah. Membuat suasana ngunggar manah, digunakan sulukan Suluk Plencung Wetah. Membuat suasana padhang, digunakan sulukan Lagon Sanga Wetah, Lagon Manyura Wetah dan Suluk Galong. Membuat suasana menep, digunakan sulukan Suluk Jingking Wetah.

\section{Hubungan cakepan (syair) dengan lagu.}

Berdasarkan penelitian terhadap sulukan versi Timbul Hadiprayitno, Hadi Sugito, dan Suparman, dapat diketahui bahwa cakepan dan lagu mempunyai hubungan yang kuat. Adapun hubungan itu dapat diperinci menjadi Cakepan dan lagu mempunyai hubungan tetap dan tidak tetap.

1. Cakepan dan lagu mempunyai hubungan tetap.

Pengertian cakepan dan lagu mempunyai hubungan tetap ialah cakepan dan lagu menyatu tidak dapat dipisahkan. Pada aspek ini terdapat kesesuaian antara kesan rasa yang ditimbulkan oleh lagu dengan kesan suasana yang dibangun oleh kalimat cakepan. Kalimat cakepan membuat dan/atau menguatkan suasana tertentu. Cakepan di sini tidak pernah dilagukan dengan lagu sulukan lain. Hal ini berlaku untuk sulukan tiga dalang itu. Berikut beberapa Lagon yang dibawakan oleh para dalang.
Lagon Nem Wetah, selalu dibawakan pada jejer pertama setelah Gendhing Karawitan suwuk Versi Timbul Hadiprayitno.

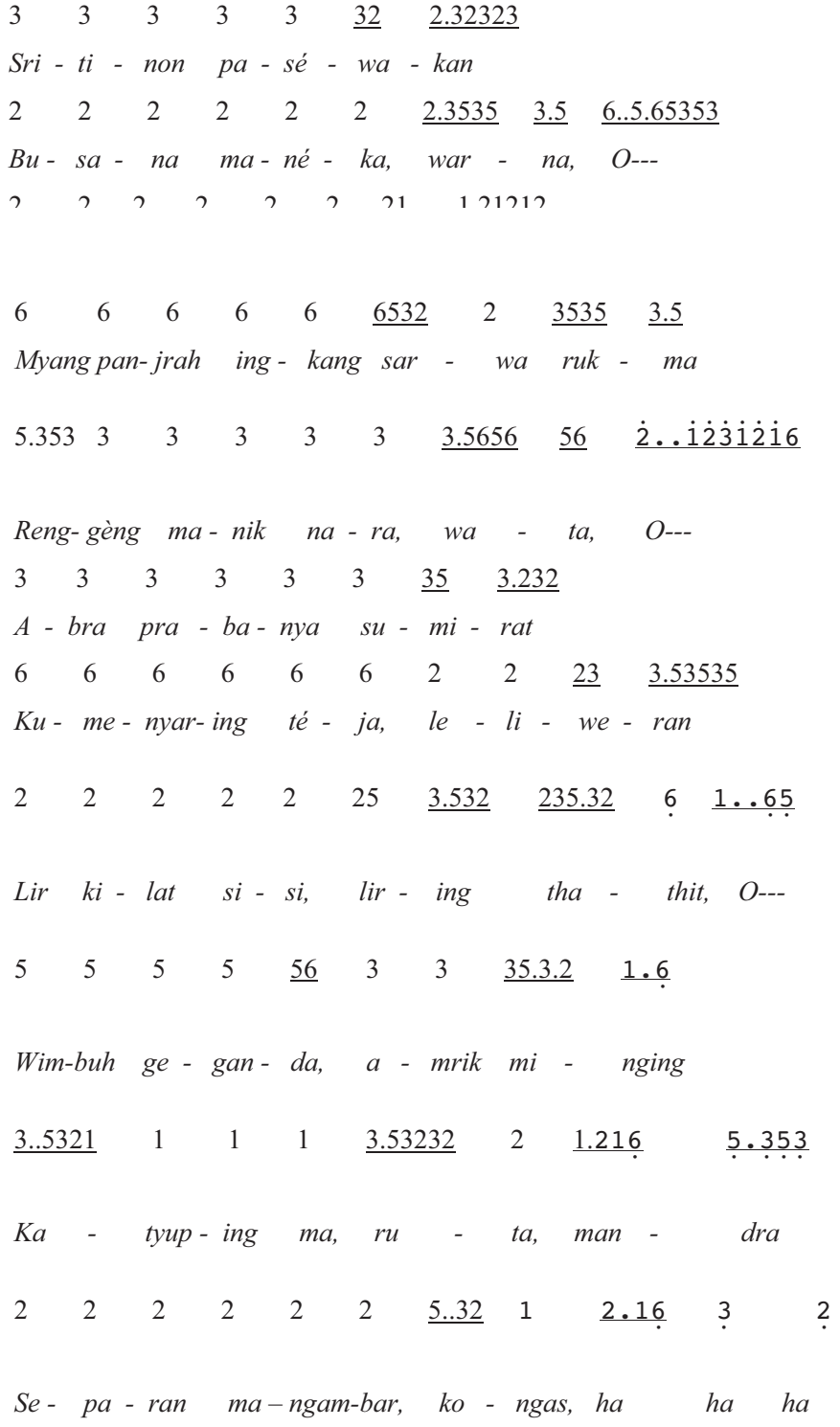

Lagon Sanga Wetah yang selalu dibawakan menjelang perubahan dari Pathet Nem ke Pathet Sanga versi Hadi Sugito.

\begin{tabular}{|c|c|c|c|c|c|c|c|c|c|c|}
\hline 2 & 2 & 2 & 2 & 2 & 2 & 2 & 2 & 2 & 2 & 2 \\
\hline$S a-$ & $y a$ & $d a$ & $l u$ & $a-$ & ra & - ras & $a$ & - byor & so & - rot \\
\hline 2 & 2 & 2 & $\underline{21}$ & 2.12 & & & & & & \\
\hline lin- & tang $k v$ & $k u-$ & me & dhap & & & & & & \\
\hline 3 & $\underline{323532}$ & & 2 & 2 & 2 & 2 & 2 & 2 & & \\
\hline$T i-$ & $t i$ & & so & - nya & $m a-$ & $d y a$ & $r a$ & tri & & \\
\hline 2.35 & 5 & 5 & 5 & 5 & 5 & 5 & 5 & & & \\
\hline
\end{tabular}


Lu - mrang gan-da - ning pus-pi - ta

i..6i.65.3.232 2

O --- na

$\begin{array}{lllllll}1 & 1 & 1 & 1.6 & 6 & 6 & 6\end{array}$

Kar - na - ning pu - dya - ni - ra

$\begin{array}{llllllll}2.121 & 1 & 1 & 1 & 1 & 1 & 1 & 1\end{array}$

Sang dwi-ja- wa - ra mbre-nge-ngeng

Lir ku - ma - ra - ning ma-du brang-ta $3.23 .2 \cdot 1 \cdot 5$

O---

Jineman

$\begin{array}{llllllll}5 & 1.61 & 2 & 2 & 5 & 32 & 321 & 6\end{array}$

Bo- cah ba - jang nggi-ring a - ngin

$\begin{array}{llllllll}35 & 2 & 5 & 3 & 2 & \underline{32} & 1 & 6\end{array}$

$A$ - na - wu ba- nyu se - ga - ra

$\begin{array}{llllllll}3 & 3 & 5 & 5.6 i & 5 & 5 & 5.3 & 2\end{array}$

Ngon $i$ - ngo-é ke - bo dhung-kul

$\begin{array}{llllllll}5.1 & 6 & 1 & 6 & 2 & 31 & 6 & 5\end{array}$

Sak-si-sih sa- pi gu- ma-rang
Lagon Manyura Wetah, yang selalu dibawakan pada waktu menjelang perubahan dari Pathet Sanga ke Pathet Manyura versi Suparman.

$\begin{array}{lllllllllll}3 & 3 & 3 & 3 & 3 & 3 & 3 & 3 & 3 & 3 & 3\end{array}$

Mèh ra - hi - na se - mu - bang Hyang Ha - ru - na

$\begin{array}{lllllllll}3.232 & 2 & 2 & 2 & 2 & 2 & 2 & \underline{212} & 2\end{array}$

$\mathrm{Ka}$ - di né - tra - ning ang-ga ra - puh

$\underline{1.23} \quad 3 \quad 3 \quad 3 \quad \underline{323} \quad 3$

Sab-da-ning $k u-k i-l a$

$\begin{array}{llllllll}\underline{3.56} & 6 & 6 & 6 & 6 & 6 & \underline{656} & 6\end{array}$

Ring $k a-n i-g a-r a s a-k e-t e r$

i. $i \dot{2} \dot{16.535 .3}$

$O---$

$\begin{array}{llllll}2 & 2 & 2 & 2 & \underline{161} & \underline{61}\end{array}$

Ke - ki - dung - an ning - kung

$\begin{array}{llllllll}6.12 & 2 & 2 & 2 & 2 & 2 & 212 & 2\end{array}$

Lir $\quad w u-w u s-i n g \quad p i-n i-p a n-c a$

$3.21 \ldots 212.16$

É---

$\begin{array}{llllllll}3 & 3 & 3 & 3 & \underline{3532} & 1 & 1 & 1\end{array}$

Pa-pe - tog-ing a - yam wa-na

$\underline{2.1232} \quad \underline{6.53} 6$

É-- $\quad$ ha $h a$

Suluk Plencung Wetah, selalu dibawakan pada waktu menjelang jejer ke dua versi Timbul Hadiprayitno.

$\begin{array}{lllllllll}6 & 6 & 6 & 6 & 6 & 6 & 6 & \underline{53} & \underline{5.65656}\end{array}$

Sri-ti - non la - ngen-ing pa - mi - yat

$\begin{array}{llllllll}2 & 2 & 2 & 2 & 2 & 2 & 21 & 1.616\end{array}$

Bu - sa - na ma-né - ka war - na

$\underline{2.35} \quad 5 \quad 5 \quad \underline{53} \quad \underline{56} \quad 5 \quad 5 \quad \underline{3232}$

Reng-gèng ken - ca - na ret - na bra 


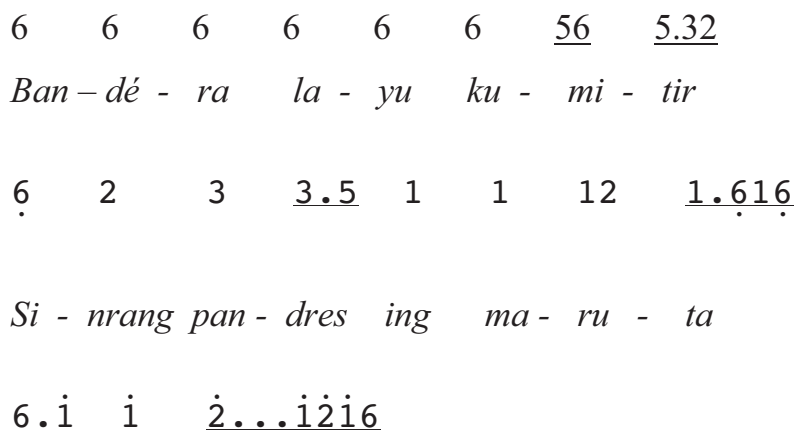

2. Cakepan dan lagu mempunyai hubungan tidak tetap.

Pengertian cakepan dan lagu mempunyai hubungan tidak tetap ialah cakepan bisa dilagukan dengan lagu sulukan lain, di samping lagu yang biasa diikutinya. Sebagai contoh bahwa suatu cakepan dapat digunakan pada Lagon Sanga Wetah maupun Suluk Plencung Jugag, yang cakepannya sebagai berikut:

Wanodya ayu utama mangambar arum, O--Mangambar aruming kusuma

Yèn ngendika èsmunya anggigit lathi

Sembada genging salira

Leléwané milangeni, O---

Liringé nétra singa mulat leng-leng brangta.
Selain itu suatu cakepan dapat digunakan pada jenis ada-ada dan jenis suluk, Adapun cakepannya sebagai berikut:

Togog malegag legog, $\mathrm{O}---$

Trembilung kang sabuk bandhil

Mbreguguk ngutha waton

Tejamaya Téjamantri, $\mathrm{O}-$--

Ngélingana déwa kang kamanungsan, ha---

3. Hubungan cakepan dengan lagu karena suasana tertentu dengan menyebut nama tokoh.

Suasana tertentu menyebabkan jenis sulukan yang dipilih adalah yang suasana itu, begitu juga cakepannya. Misal tokoh dalam keadaan marah maka dipilih sulukan jenis ada-ada yang cakepannya tentang tokoh itu. Sebagai contoh, Cakepan Adaada Nem Jugag oleh Timbul Hadiprayitno dengan menyebut nama tokoh Sencaki.

Sencaki tinulu wirang tumandang

Kadi setyan garwanira Sencaki Mandraatmaja, $O$---

Sedyaning prang kontit saliranira

Winewes riya Burisrawa, ha---

Cakepan Ada-ada Nem Wetah oleh Hadi Sugita dengan menyebut nama tokoh Durna.

Durna panalinganira

Lumajaring ratri, $O$---

Cinandhak Risang Trusthajumena kapisanan

Linenggak jangga tinigas mustaka

Binuncang sunundhul ing akasa, O---

Ngélingana duk patiné Sang Hèstitama, ha---

Cakepan Ada-ada Nem Jugag oleh Suparman dengan menyebut nama tokoh Baladéwa

Baladéwa setiti nenggalanira pamuk

Sri Baladéwa narpati tinarswala Kresna

Langkung ing tresnanira marang Dyah Banoncinawi, ha---

4. Hubungan cakepan dengan lagu karena suasana tertentu dengan tidak menyebut nama tokoh.

Cakepan Suluk Plencung Jugag Timbul Hadiprayitno.

Wanodya ayu mangambar arum, $O--$

Mangambar aruming kusuma

Yèn ngendika èsmunya anggigit lathi 


\section{Sembada genging salira}

Leléwané milangeni, $O---$

Liringé nétra singa mulat leng-leng brangta.

\section{Cakepan Ada-ada Nem Jugag Hadi Sugito \\ Mundur saking ayuda \\ Mulat ponang pra wadyabala \\ Jaja bang mawinga-winga, ha---}

\section{Cakepan Ada-ada Nem Wetah Suparman \\ Mijil saking jroning praja \\ Kondhanging pra wadya sawéga, $O---$}

Puksur tambur myang suling pepandhèn daludag

Miwah bandéra kekandha warna-warna

Pindha jaladri asri kawuryan, $\mathrm{O}$

Hubungan gendhing dengan sulukan dari dalang Timbul Hadiprayitno, Hadi Sugito, dan Suparman adalah sama, dapat diperinci sebagai berikut: (1) Gendhing dan sulukan mempunyai hubungan tetap, artinya bahwa gendhing $\mathrm{X}$ sulukannya tentu Y. Hal ini dapat dilihat pada jejer pertama, jejer negara manapun tentu menggunakan Gendhing Karawitan. Gendhing Karawitan ini digunakan sebagai iringan janturan (narasi). Setelah janturan selesai, gendhing disuwuk kemudian selalu dilanjutkan dengan sulukan Lagon Nem Wetah. (2) Gendhing dan sulukan mempunyai hubungan tidak tetap. Artinya bahwa Gendhing X belum tentu disuluki dengan Y, akan tetapi dapat dengan sulukan lain, misalnya Srepeg suwuk dapat disuluki dengan ada-ada, dan dapat juga disuluki dengan lagon, tergantung pada suasana yang akan dicapai.

\section{Perbedaan Sulukan}

Pada awal uraian telah dikemukakan, bahwa sulukan Timbul Hadiprayitno, Hadi Sugito, dan Suparman terdiri atas empat jenis yakni: lagon, suluk, kawin, dan ada-ada. Pada jenis lagon, suluk, dan kawin pada dasarnya lagu pokok sulukan sama, sedangkan perbedaannya terletak pada wilet. Adapun yang dimaksud dengan lagu pokok adalah nada pada awal baris dan akhir baris. Sedangkan yang dimaksud dengan wilet adalah banyaknya nada pada setiap suku kata. Agar lebih jelas akan dicontohkan Lagon Nem Wetah dari tiga dalang itu pada baris pertama, ke dua, tiga, ke empat, dan ke lima sebagai berikut.
Baris pertama Lagon Nem Wetah

Timbul Hadiprayitno

$$
\begin{array}{lllllll}
3 & 3 & 3 & 3 & 3 & \underline{32} & \underline{2.32323} \\
S r i-t i-n o n & p a-s e ́-w a-k a n
\end{array}
$$

Hadi Sugito

$$
\begin{array}{cccccccc}
3 & 3 & 3 & 3 & 3 & 3 & 3 & \underline{23} \\
& S r i-t i-n o n & i n g & p a-s e ́ & -w a-k a n
\end{array}
$$

\section{Suparman}

$\begin{array}{llllllll}3 & 3 & 3 & 3 & 3 & 3 & \underline{32} & \underline{2.123} \\ S r i-t i & -n o n & i n g & p a-s e ́-w a-k a n\end{array}$

Lagon Nem Wetah baris pertama dari ketiga dalang itu berawal dari nada 3 dan berakhir pada nada 3. Inilah yang dimaksud dengan lagu pokok tiga dalang itu sama. Adapun perbedaannya terletak pada wilet. Wilet adalah banyaknya nada setiap suku kata. Pada baris pertama Lagon Nem Wetah Timbul Hadiprayitno, suku kata menjelang akhir baris terdiri atas dua nada (32 dengan cakepan wa), dan suku kata pada akhir baris terdiri atas enam nada (2.32323 dengan cakepan kan). Sedangkan baris pertama versi Hadi Sugito, pada akhir baris terdiri atas dua nada (23 dengan cakepan kan). Adapun baris pertama versi Suparman, pada suku kata menjelang akhir baris terdiri atas dua nada (32 dengan cakepan wa) dan suku kata pada akhir baris terdiri atas empat nada (2.123 dengan cakepan kan). Selain itu pada cakepan Timbul Hadiprayitno ada perbedaan sedikit dengan lainnya yakni tanpa kata "ing".

Baris ke dua

Timbul Hadiprayitno

$\begin{array}{lllllllll}2 & 2 & 2 & 2 & 2 & 2 & \underline{2.3535} & \underline{35} & \underline{6 . .5 .653532}\end{array}$

Bu-sa-na ma-né-ka, war - na o...

Hadi Sugito

$\begin{array}{lllllllll}2 & 2 & 2 & 2 & 2 & 2 & \underline{2.3} & 5 & \underline{6.53 . .5 .32}\end{array}$

Bu-sa-na ma-né-ka, war-na, o... 
Suparman

\section{$\begin{array}{lllllllll}2.35 & 5 & 5 & 5 & 5 & 5 & 535 & 5 & 6 \ldots 56.53 . .535 . .32\end{array}$}

Bu - sa-na ma-né- ka war-na, o...

Pada baris ke dua tiga dalang berawal dari nada 2 dan berakhir dengan nada 2. Adapun perbedaan yang mencolok terletak pada wilet. Sulukan Timbul Hadiprayitno, suku kata ketujuh terdiri atas lima nada (2.3535 dengan cakepan war), dan suku kata kedelapan terdiri atas dua nada (35 dengan cakepan na), serta suku kata ke delapan terdiri atas delapan nada (6..5.653532 dengan cakepan $O$ ). Sedangkan sulukan Hadi Sugito, suku kata ke tujuh terdiri atas tiga nada (2.35 dengan cakepan war), dan suku kata terakhir terdiri atas enam nada (6.53.5.32 dengan cakepan $O)$. Adapun sulukan Suparman pada suku kata pertama terdiri atas tiga nada (2.35 dengan cakepan bu), dan pada suku kata ke tujuh terdiri atas tiga nada (535 dengan cakepan war), serta pada suku kata terakhir terdiri atas sepuluh nada (6...56.53..535..32 dengan cakepan $O)$.

Baris ke tiga

Timbul Hadiprayitno

$\begin{array}{llllllll}2 & 2 & 2 & 2 & 2 & 2 & \underline{21} & \underline{1.21212}\end{array}$

Se-bak pus-pi-tèng $h u-d y a-n a \ldots$

Hadi Sugito

$\begin{array}{llllllll}\underline{6.12} & 2 & 2 & 2 & 2 & 2 & \underline{3 . .212} & 2\end{array}$

Sé - bak pus-pi-tèng hu-dya- na

Suparman

$\begin{array}{llllllll}\frac{6.12}{6} & 2 & 2 & 2 & 2 & 2 & \underline{212} & 2 \\ S e ́ & -b a k & p u s & -p i \text { - tèng } & h u-d y a-n a\end{array}$

Pada baris ke tiga versi Timbul Hadiprayitno diawali dengan nada 2, sedangkan Hadi Sugito dan Suparman diawali dengan nada 6. Pada akhir baris tiga dalang mengakhiri dengan nada 2. Adapun perbedaan wilet adalah sebagai berikut. Sulukan Timbul Hadiprayitno pada suku kata ke tujuh terdiri atas dua nada (21 dengan cakepan dya), dan suku kata terakhir terdiri atas enam nada (1.21212 dengan cakepan na). Sedangkan sulukan Hadi Sugito pada suku kata awal terdiri atas tiga nada (6.12 dengan cakepan sé), dan pada suku kata ke tujuh terdiri atas empat nada (3..212 dengan cakepan dya). Adapun sulukan Suparman pada suku kata awal terdiri atas tiga nada (6.12 dengan cakepan sé), dan pada suku kata ke tujuh terdiri atas tiga nada (212 dengan cakepan dya). Cakepan Timbul Hadiprayitno sedikit berbeda dengan ke dua dalang lainnya yakni pada kata yang pertama Timbul Hadiprayitno mengatakan sobak sedangkan ke dua dalang lainnnya mengatakan sébak.

Baris ke empat

Timbul Hadiprayitno

$\begin{array}{lllllllll}6 & 6 & 6 & 6 & 6 & \underline{6532} & 2 & \underline{3535} & \underline{3.5}\end{array}$

Myang pan-jrah ing-kang sar-wa ruk-ma

Hadi Sugito

$\begin{array}{lllllll}6 & 6 & 6 & 6 & 6 & \underline{532.35} & 5\end{array}$

Myang pan-jrah sar-wa ruk - ma

Suparman

$\begin{array}{llllllll}6 & 6 & 6 & 6 & \underline{6 . .56} & 5 & \underline{53} & \underline{35}\end{array}$

Myang pan-jrah-ing sar-wa ruk-ma

Pada baris yang ke empat ini lagu pokok tiga dalang sama yakni diawali dengan nada 6 dan berakhir dengan nada 5. Sedangkan wiletnya tidak sama yakni sebagai berikut. Sulukan Timbul Hadiprayitno pada suku kata ke enam terdiri atas empat nada (6532 dengan cakepan sar), dan pada suku kata ke delapan terdiri atas empat nada (3535 dengan cakepan ruk), serta pada suku kata yang terakhir terdiri atas dua nada (3.5 dengan cakepan ma). Sulukan Hadi Sugito pada suku kata ke enam terdiri atas lima nada (532.35 dengan cakepan ruk). Adapun sulukan Suparman pada suku kata ke lima terdiri atas empat empat nada (6..565 dengan cakepan sar), dan pada suku ke tujuh terdiri atas dua nada (53 dengan cakepan ruk). Serta pada suku kata terakhir terdiri atas dua nada (35 dengan cakepan ma).

Cakepan di dalam baris ke empat ini tiga dalang ada perbedaan sedikit sebagai berikut. Sulukan Timbul Hadiprayitno pada suku kata ke empat ada cakepan ingkang, sedangkan sulukan 
Hadi Sugito tanpa cakepan ingkang, dan sulukan Suparman hanya menggunakan cakepan ing saja tanpa kang.

Baris ke lima

Timbul Hadiprayitno

\section{$\begin{array}{llllllll}\underline{5.353} & 3 & 3 & 3 & 3 & 3 & \underline{3.5656} & \underline{56}\end{array}$}

Reng-gèng ma-nik na-ra wa - ta

Hadi Sugito

$\begin{array}{llllllll}53 & 3 & 3 & 3 & 3 & 3 & \underline{356} & 6\end{array}$

Reng-gèng na-nik na-ra wa- ta

Suparman

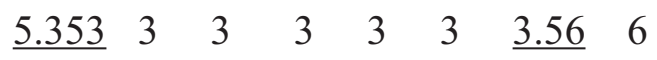 \\ Reng-gèng ma-nik na-ra wa- ta}

Pada baris ke lima, lagu pokok tiga dalang sama yakni diawali dengan nada 5 dan berakhir dengan nada 6. Sedangkan wilet-nya tidak sama yakni sebagai berikut. Sulukan Timbul Hadipratitno pada awal baris terdiri atas empat nada (5.353 dengan cakepan reng), dan pada suku kata ke tujuh terdiri atas lima nada (3.5656 dengan cakepan $w a)$, serta pada akhir baris terdiri atas dua nada (56 dengan cakepan ta). Sulukan Hadi Sugito permulaan baris terdiri atas dua nada (53 dengan cakepan reng), dan pada suku kata ke tujuh terdiri atas tiga nada (356 dengan cakepan wa). Adapun sulukan Suparman pada permulaan baris tediri atas empat nada (5.353 dengan cakepan reng), dan pada suku kata ke tujuh terdiri atas tiga nada (3.56 dengan cakepan wa).

Sulukan jenis ada-ada dapat diperinci menjadi dua macam yakni: (1) Lagu pokok sama, perbedaannya pada wilet dan cakepan. Contoh: Ada-ada Nem Jugag dari tiga dalang sebagai berikut.

Versi Timbul Hadiprayitno

\section{$\begin{array}{llllllll}2 & 2 & 2 & 2 & 2 & 2 & 2 & 2\end{array}$}

Di-pa kang ke-ba-wat ma-ja

$$
\begin{array}{llllllllll}
3 & 3 & 3 & 3 & 3 & 3 & 3 & 3 & 3 & 3
\end{array}
$$

Ku-me-pruk ti- ba-ning ra-raga ra-ga

$$
\begin{aligned}
& \begin{array}{lllllll}
3 & 3 & 3 & 3 & 3 & 3 & \underline{2 \ldots 163}
\end{array} \\
& M a-t i \quad k e-p a-n a s-a n \quad o . . . \\
& \begin{array}{lllllll}
2 & 2 & 2 & 2 & 2 & \underline{32} & 6
\end{array} \\
& \text { Ma- ti - né - nga-la - ga, ha }
\end{aligned}
$$

Versi Hadi Sugito

$\begin{array}{llllllllll}2 & 2 & 2 & 2 & 2 & 2 & 2 & 2 & 2 & 2\end{array}$

Pan-dhi-ta ki-nar-ya wang-sit pin-dha

22

kom-bang

$\begin{array}{llllllllll}6 & 6 & 6 & 6 & 6 & 6 & 6 & 6 & 6 & 6\end{array}$

Ne-sep- a ma-du sa-ri-ning ta-wang

2...i2..i 16.5 .35 .3

o.

$\begin{array}{lllllllll}2 & 2 & 2 & 2 & 2 & 2 & 2 & \underline{2.121} & 1\end{array}$

Me-dhar-na ngèl-mu kang sa-nya- ta $r^{\text {II }}$

$321212 \quad 6$

o....... ha......

Versi Suparman

$\begin{array}{llllllll}2 & 2 & 2 & 2 & 2 & 2 & 2 & 2\end{array}$

Ri - kat - a Sang Ga-thut - ka - ca

$\begin{array}{llll}2 & 2 & 2 & 2\end{array}$

ki - nèn ma-pag

$\begin{array}{llllllll}1 & 2 & 3 & 3 & 3 & 3 & 3 & 3\end{array}$

$K i$ - nèn ma-pag ar - $k a \quad s u$ - ta

35

$a r-k a$

$323 \quad 53 \quad 2 . .1216 .535 .3$

$s u-t a$, 


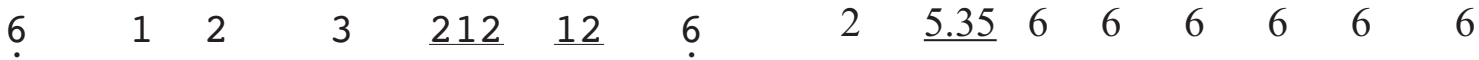

$$
\begin{aligned}
& \text { Te-kap-i - ra Kres-na, ha--- Sa-mi-ra-na a-wor ku - la } \\
& \text { Lagu pokok, wilet, dan cakepan tidak sama. } \\
& 6 \quad 6 \quad 6 \quad i .6 i \cdot 65 \cdot 3.23 .2 \\
& \text { Ada-ada Sanga Wetah untuk gara-gara. } \\
& \text {-wan ri - ris o............ } \\
& \text { Versi Timbul Hadiprayitno. } \\
& \dot{2} \quad \dot{2} \dot{i} \dot{2} \dot{3} \\
& O \ldots \ldots \ldots . \quad O O \ldots \ldots \ldots . . \\
& \text { i } \quad \text { i } \quad \text { i } \quad \text { i6i } 6.16 i 6 i \\
& \begin{array}{llllllll}
5 & 6 & 1 & 1 & 1 & 1 & 1 & 1
\end{array} \\
& \text { Lu-mrang gan-da-ning pus-pi- ta } \\
& \begin{array}{lllllll}
6 & 6 & 6 & 6 & 6 & 6 & \underline{6.532}
\end{array} \\
& \text { Ti - ti so - nya ma-dya ra - } \\
& \text { Su - kra mang-ka - ra } \\
& 2 \quad 5.3532 .6 .5
\end{aligned}
$$

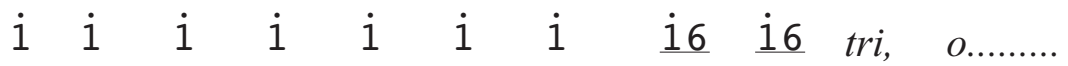

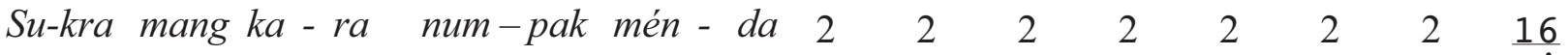
$55 \quad \underline{323} \underline{23.21235} \dot{2} \mathrm{i} \dot{2} \dot{i} 6 \quad$ Ra-ras ru-men-dhènging a - ka Ti - tik - an na - ba

$12 \quad 2.3 .2321 \quad 5$

$\begin{array}{lllllll}5 & 5 & 5 & 5 & 5 & 5 & 5\end{array}$

$-s a$, ha...

Ti - tik - an na - ba so - ma

$\begin{array}{lllll}5 & 5.32 & 5 & 1.21 & \mathbf{2} \mathrm{i} \dot{\mathrm{i}} 6\end{array}$

Versi Suparman

war-ji - ta ha o.......

$\dot{2} \quad \dot{2} \quad \dot{2} \quad \dot{2} \quad \dot{2}$

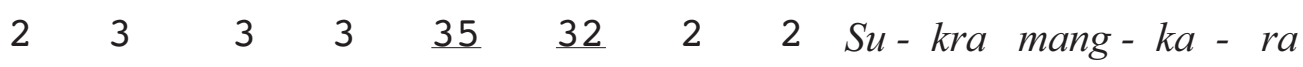
Ang-ga-ra re- $k a-t h a \quad b u-d a \underline{2 .} \dot{1} \dot{1} \quad$ i $65 \quad 56 \dot{1}$

$2 \quad 21 \quad 165$

$m a-e ́-s a$

$\begin{array}{llllllllll}2 & 2 & 2 & 2 & 2 & 232 & 3.21 & 5 & 2\end{array}$

Ba-nas pa-ti min-tu-na, ha...o

Versi Hadi Sugito

$\begin{array}{llllllll}5 & 6 & i & i & i & i & i & i\end{array}$

Ka-yon ka-ti-yup-ing a-ngin

$\begin{array}{lllllllll}6 & 6 & 6 & 6 & 6 & 6 & \underline{6.532} & 2 & \underline{2.35}\end{array}$

Su-myak swa-ra-ning ka re - ngyan sa-

$5 \quad 5 \quad 5$

$m i-r a-n a$
Tum - pak mén- da

$\begin{array}{lllllllll}6 & 6 & 6 & 6 & 6 & 6 & 6 \dot{1} \dot{2} & \dot{2} & \dot{2}\end{array}$

Tum-pak mén-da dé-dé ka-la-ba

$\begin{array}{lllll}6 & 6 & 6 & \underline{535} & \underline{3.53535}\end{array}$

So - ma wer - ji - ta

i..i் $\dot{16}$

$O \ldots$

$\begin{array}{llllll}5 & 5 & 5 & 5 & 5.32 & 2\end{array}$

Ang-ga - ra re - $k a$ - tha

$\begin{array}{llllll}1 & 1 & 2 & 161 & 6.16161 & 6\end{array}$

$B u$ - ta ma-é - sa,

ha......... 


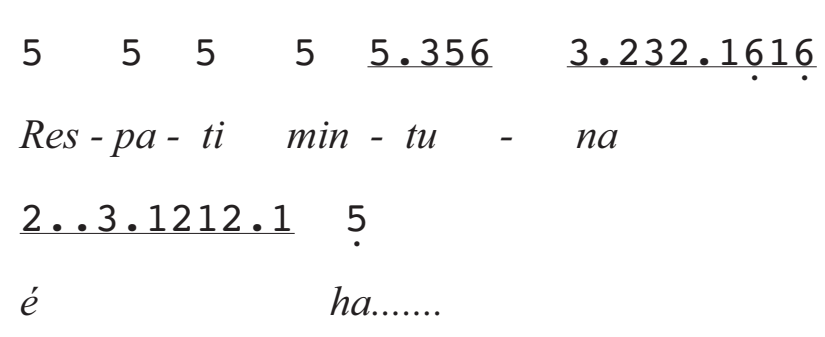

Selain itu ada perbedaan-perbedaan yang akan dikemukakan sebagai berikut. Timbul Hadiprayitno dan Suparman membedakan sulukan yang digunakan pada jejer pertama. Pada jejer pertama Negara Astina, setelah Lagon Nem Wetah dilanjutkan dengan Kawin Sikarini, sedangkan untuk selain jejer Negara Astina menggunakan Kawin Girisa. Berbeda dengan Hadi Sugito, ia tidak membedakan jejer pertama Negara Astina atau negara selain Astina, akan tetapi negara manapun menggunakan Kawin Girisa. Menurut Hadi Sugito, penggunaan Kawin Girisa untuk semua negara itu didasarkan atas pertimbangan bahwa Kawin Girisa lebih netral, bisa digunakan untuk negara manapun, dengan hanya mengganti nama raja.

Timbul Hadiprayitno dan Suparman mempunyai sulukan Lagon Sanga Ngelik, mengambil dari Surakarta yang penyajiannya disesuaikan dengan kemantapannya. Sedangkan Hadi Sugito tidak mempunyai sulukan Lagon Sanga Ngelik. Hadi Sugito dan Suparman tidak pernah menampilkan sulukan Suluk Galong. Dalam hal ini Hadi Sugito memberi alasan teknis yakni karena waktu telah habis (karahinan) sehingga tidak sempat untuk menampilkan Suluk Galong, akan tetapi langsung menampilkan $A d a$-ada Galong. Lain dengan Timbul Hadiprayitno, ia tetap menampilkan Suluk Galong.

Hadi Sugito dalam menyajikan sulukan Lagon Sanga Wetah untuk perubahan pathet dari Pathet Nem ke Pathet Sanga, dilanjutkan dengan jineman, dengan cakepan: "Bocah bajang nggiring angin, anawu banyu segara, ngoningoné kebo dhungkul, saksisih sapi gumarang", sedangkan Timbul Hadiprayitno dan Suparman tidak menampilkan jineman.

Berdasarkan uraian di depan dapat ditentukan ciri-ciri sulukan Timbul Hadiprayitno, Hadi Sugito, dan Suparman sebagai berikut.

\section{Ciri-ciri sulukan Timbul Hadiprayitno}

1. Wilet

a) Suku kata menjelang akhir baris terdiri atas tiga nada dan suku kata akhir baris terdiri atas enam nada. Contoh sebagai berikut.

$\begin{array}{llllllll}\underline{3.56} & 6 & 6 & 6 & 6 & 6 & \underline{656} & 5.65656\end{array}$

Ring -ka - ni - ga -ra sa - ke - ter

b). Pada cakepan $\mathrm{O}$ terdiri atas enam nada. Contoh sebagai berikut.

\section{$\dot{3} \dot{5} \dot{3} \dot{2} \dot{3} \dot{2}$}

$0 . . . . .$.

c) Suku kata menjelang akhir baris terdiri atas nada dan pada suku kata terakhir terdiri atas sebelas nada. Contoh sebagai berikut.

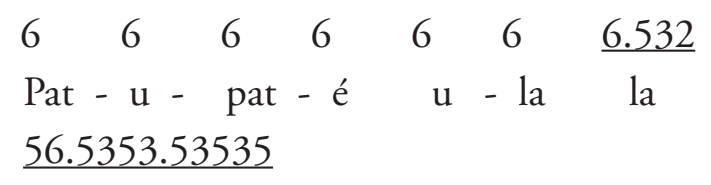

- nang

d) Suku kata menjelang akhir baris terdiri atas dua nada dan suku kata pada akhir baris terdiri atas empat nada. Contoh sebagai berikut.

$$
\begin{array}{lllllll}
6 & 6 & 6 & 6 & 6 & 65 & \mathbf{1} .616
\end{array}
$$

Wi - sik - an ma - gu - ling - an

2. Cakepan

Cakepan suluk Tlutur Wetah

$O$, ha, ha

Ana dhandhang saka sabrang apa

Rupaning dhangdhang

Cucuk wesi pulosrani

Laring pedhang aja nucuk sri sedana

Nucuka sarap swané wong sukerta

Adohna tekan segara kidul, ha

Pujèkna teguh wiyana slamet, ana, ha.

3. Sulukan

Sulukan Ada-ada Sanga Wetah, untuk perang kembang

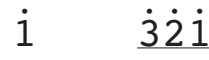

o................... 


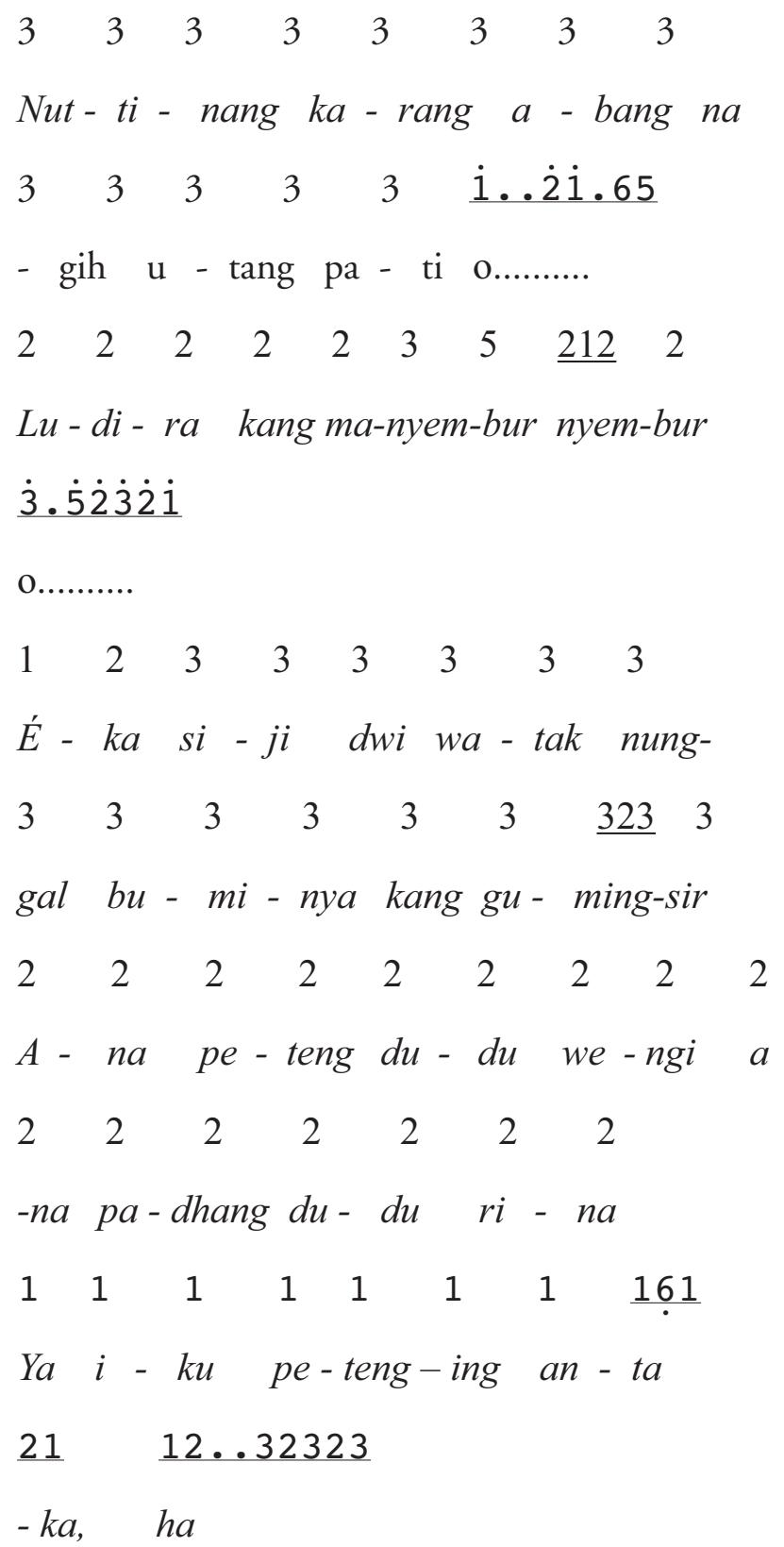

\section{Ciri-ciri sulukan Hadi Sugito}

1. Wilet

a) Pada cakepan $\mathrm{O}$ terdiri atas sembilan nada, contoh sebagai berikut.

$$
\text { 2.. í } \dot{1} \text { i } 6.5 .35 .3
$$

o.

b) Pada cakepan $\mathrm{O}$ menjelang akhir sulukan yang terdiri atas enam nada dan dimulai dari nada 1 . Contoh sebagai berikut.

\section{$\underline{1.21212}$}

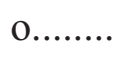

c) Pada cakepan $\mathrm{O}$ menjelang akhir sulukan yang terdiri atas enam nada dan dumulai dari nada 3. Contoh sebagaiberikut.

\section{3..5.35.32}

$\mathrm{O}$...........

d) Pada cakepan $\mathrm{O}$ menjelang akhir sulukan yang terdiri atas 15 nada. Contoh sebagai berikut.

$$
\begin{array}{ll}
\dot{2} . \mathrm{i} \dot{2} . \mathrm{i} 6.5 .35 .3 & 3.535 .32 \\
\text { O..... } & \text { O....... }
\end{array}
$$

2. Cakepan

a) Cakepan Suluk Tlutur Wetah

Balé lumut ambreganggeng, $O---$

Suksma ilang kontrang-kantringan

Oncaté suksma dhedhèncèngan

Lir ganggeng kulawan lumut

Manut ilining tirta

Lelambat tumekèng samodra

Lebur katiyuping mandra, ha

b) Cakepan Ada-ada Sanga Wetah, untuk gara-gara menggunakan cakepan sebagai berikut.

$O$.......

Kayon katiyuping angin

Sumyak swaraning karengyan samirana

Samirana awor kulawan riris

O

Lumrang gandaning puspita

Titi Sonya madya ratri, $O$.......

Raras rumendhèng ing akasa, $O$......, ha

c) Cakepan Ada-ada Sanga Jugag

Macan mudhun sangka nggunung

Manut ilining tirta tumuruning jurang

Wusnya manjing thelenging wana

kumrasak swaraning jaladri

Wusnya kang tumibèng talaga

Surup ratri sima kang nginum warih, ha

3. Sulukan

Pada Sulukan Lagon Sanga Wetah untuk perubahan pathet dari Pathet Nem ke Pathet Sanga, ditambah jineman dengan cakepan 
"Bocah bajang nggiring angin. anawu banyu segara, ngoningoné kebo dhungkul, saksisih sapi gumarang."

\section{Ciri-ciri Sulukan Suparman}

1 Wilet

a) Pada cakepan $\mathrm{O}$ tediri atas 10 nada. Contoh sebagai berikut.

\section{i. $\dot{1} \dot{i}$.6.5356.3 \\ O........}

b) Pada cakepan $\mathrm{O}$ menjelang akhir sulukan yang terdiri atas tujuh nada. Contoh sebagai berikut.

3.52323 .2

O........

2. Cakepan

a) Ada-ada Nem Jugag

Dhuh wayah non tumon wong aprang yèn kasasaran

Kasasaran nèng madyaning ngalaga

Lumadya angroning sekar manglir bawan lamun mangsah

mba lir juladri samodra hangron, ha

b) Ada-ada Nem Jugag

Marpating angin-angin upayanen

tribawana

O---

Kadi nganing awang-awang

Padhang dudu raina peteng dudu wengi,

$O$, ha.

c) Ada-ada Manyura Jugag

Ratu gumulung pangruwating waja, ha

Kandheg krendha taranbaya

Tan kilat-kilating wasta

Gumregut magut mangajap, $O$, ha.

\section{Perbedaan Sulukan Timbul Hadiprayitno, Hadi Sugito, dan Suparman}

Tiga dalang yakni Timbul Hadiprayitno, Hadi Sugito, dan Suparman merupakan dalang yang kreatif. Mereka tidak puas hanya mendapatkan warisan berupa pedalangan khususnya sulukan dari orang tuanya. Selain sulukan didapatkan dari orang tua, mereka juga mengembangkan dengan cara selalu melihat pertunjukan wayang di mana berada dengan tidak membeda-bedakan dalang siapa yang tampil. Hal ini terjadi karena mereka berpendapat bahwa sejelek-jeleknya seorang dalang tentu ada kelebihannya pada ssi yang lain. Oleh karena itu kelebihannya yang diambil.

Pakeliran Timbul Hadiprayitno dapat dikatakan sebagai ramuan dari tiga dalang yakni Bancak, Gondomargono, dan Nartosabdo. Khusus sulukan, ia memadukan dari Bancak dan Gondomargono yang kemudian diolah menjadi sulukan khas Timbul Hadiprayitno. Sedangkan Hadi Sugito tidak mempunyai idola, ia menganggap bahwa semua dalang tentu ada kelebihannya dan kekurangannya, sehingga yang harus diambil adalah kelebihannya. Adapun Suparman mempunyai idola yakni dalang Jayèng.

Tiga dalang itu tidak begitu saja menerima warisan dari orang tuanya apa adanya, akan tetapi mereka berusaha mengubah warisan itu supaya tetap hidup pada zamannya. Hal itu menunjukkan bahwa mereka ingin memberikan sumbangan warisan budaya pada zamannya dan generasi berikutnya. Seperti yang dikemukakan oleh Maurice Duverger (1981: 256) bahwa: "Tidak ada generasi yang puas dengan warisan pusaka, dalam hal ini sulukan yang diterimanya dari masa lalu, ia membuat sumbangannya sendiri."

Timbul Hadiprayitna dalam mengembangkan sulukan mengambil dari gaya (1) Habirandha, (2) dari luar Habirandha, dan (3) dari Surakarta. Sulukan Habirandha yang diambil terutama jenis lagon seperti Lagon Nem Wetah, Lagon Sanga Wetah, dan Lagon Manyura Wetah. Hal ini dimungkinkan karena ia pernah kursus di Habirandha pada tahun 1957, walaupun ia telah menjadi dalang. Sedangkan sulukan jenis ada-ada diambil dari luar Habirandha.

Hadi Sugito dalam mengembangkan sulukan, selain didapat dari orang tuanya juga meniru dari dalang-dalang lainnya dan dari membaca buku, serta dari fenomena alam, misal Ada-ada Sanga Jugag yang cakepannya sebagi berikut:

\footnotetext{
Macan mudhun sangka nggunung Manut ilining tirta, tumuruning jurang Wusnya manjing thelenging wana kumrosak swaraning jaladri

Wusnya kang tumibèng talaga

Surup ratri sima kang nginum warih.
} 
Suparman, kecuali sulukan-nya diterima dari orang tuanya, kemudian dikembangkan dengan cara meniru dalang yang menjadi idolanya dan mengambil dari Habirandha terutama pada jenis lagon. Selain itu ia paling banyak mengambil sulukan Surakarta dibandingkan dengan Timbul Hadiprayitno dan Hadi Sugito. Misalnya, Lagon Sanga Ngelik lagu dan cakepan-nya mengambil dari Surakarta. Selain itu banyak cakepan yang diambil dari Surakarta seperti:

Cakepan Ada-ada Nem Wetah

Tan samar pamoring suksma

Sinuksmaya ywa hasepi

Sinimpen thelenging kalbu

Pambukaning warana

Tarlèn tyas liyep layaping aluyup

Pindha pesating sumpena

Sumusuping rasa jati.

Cakepan Ada-ada Nem Wetah

Mundur sang rekyana patih

Undhanging pra wadya bala sawéga

Umyung swaraning bendhé bèri

Pa pa gurnang kalawan

Puksur tambur myang suling pepandhèn $d a-$ ludag

Miwah bandéra kakandha warna-warna.

Cakepan Ada-ada Girisa

Yaksa gora risedheng naréndra

Yaksa lelaku kan wal walèngkang

Gambira rangah angisis siyung

Metu prabawa lésus prakempa

Gora mawalikan

Singa pawalta curnaning lawan

Tuwi wira, rodra.

Selain tidak puas terhadap hasil yang telah ada, tiga dalang memang orang yang ahli dalam bidang pedalangan. Ini tidak mengherankan karena mereka adalah turun dalang. Sejak kecil sudah terbiasa dan terlatih dengan wayang, karena setiap ayahnya mendalang anaknya tentu ikut. Dengan demikian mereka terbiasa mendengarkan suara gamelan yang berlaras slendro dan pelog, terbiasa mendengarkan perbedaan suara wayang satu dengan yang lain, terbiasa mendengarkan janturan, dan terbiasa mendengarkan sulukan. Dengan dasar yang kuat ini tidak mustahil pada gilirannya tumbuh dan berkembang menjadi dalang yang potensial dan berkembang luar biasa.
Tiga dalang tersebut tentunya tidak dapat lepas dari keinginan mendapatkan imbalan. Imbalan yang mereka harapkan ada dua macam yakni imbalan berupa materi dan imbalan berupa nama. Imbalan yang berupa materi ini dapat dilihat bahwa tiga dalang merupakan dalang yang laris di daerah Yogyakarta. Dengan kelarisannya itu mereka menjadi kaya dan banyak uang. Imbalan yang lain adalah berupa nama atau penghargaan. Dengan kemampuannya mereka menjadi dalang yang laris, sehingga kemudian mempunyai status sosial tinggi. Selanjutnya masyarakat khususnya pendukung pedalangan akan menghargainya.

\section{Penutup}

Berdasarkan pembahasan di depan dapat disimpulkan bahwa pakeliran gaya Yogyakarta mempunyai beberapa ragam gaya seperti ragam gaya keraton (Habirandha) dan ragam gaya di luar keraton atau ragam gaya kerakyatan, seperti pakeliran Timbul Hadiprayitno, Hadi Sugito, dan Suparman.

Pakeliran tiga dalang yang diteliti mempunyai ciri-ciri tersendiri, yang paling menonjol terletak pada sulukan. Sulukan tiga dalang itu mempunyai persamaan dan perbedaan. Adapun persamaannya terletak pada (1) pathet (nem, sanga, mnyura), (2) Jenis (lagon, suluk, kawin, dan ada-ada), (3) fungsi (struktural dan estetis), (4) hubungan cakepan dengan lagu, (5) hubungan gendhing dengan sulukan. Apapun perbedaannya terletak pada (1) wilet (2) Timbul Hadiprayitno dan Suparman pada jejer pertama menggunakan sulukan Kawin Sikarini untuk Negara Astina dan untuk negara selain Astina menggunakan sulukan Kawin Girisa. Akan tetapi pada sulukan Hadi Sugito, pada jejer negara manapun digunakan Kawin Girisa.

\section{Kepustakaan}

Murtiyoso, Bambang. 1982/1983. Pengetahuan Pedalangan. Surakarta: Proyek Pengembangan IKI Sub Proyek ASKI.

Clara Van Groennendael, Victoria M. 1987. Dalang di Balik Wayang. Jakarta: Pustaka Utama Grafiti.

Duverger, Maurice. 1981. Sosiologi Politik. Terjemahan Daniel Dhakidae. Jakarta: Rajawali.

Gorys Keraf. 1982. Eksposisi dan Diskripsi. Ende: Nusa Indah. 
Harahap. E. St. 1951. Kamus Indonesia. Bandung: Soedarso Sp. 1990. Tinjauan Seni. Yogyakarta: Kalfeko. Suku Dayar Sana Yogyakarta.

Holt, Clair. 1992. Seni di Indonesia Kontinuitas Sri Mulyono. 1989. Wayang Asal Usul, Filsafat dan dan Perubahannya. Yogyakarta: Institut Seni Indonesia Yogyakarta.

Koentjaraningrat. 1983. Pengantar Ilmu Antropologi. Jakarta: Aksara Baru.

Mudjanattistomo, dkk. 1977. Pedalangan Ngayogyakarta Jilid I. Yogyakarta: Habirandha.

Nojowirongko al. Atmotjendono. 1958. Serat Tuntunan Pedalangan Tjaking Pakeliran Lampahan Irawan Rabi. Yogyakarta: Tjabang Bagian Bahasa Yogyakarta Djawatan Kebudajaan Kementrian P.P. dan K.

Prawiro Atmodjo. 1994. Bau Sastra Jawa. Surabaya: Djajabojo.

Purwadarminto W.J.S.1939. Bau Sastra Jawa. Groningen: J.B. Wolters Masa Depannya. Jakarta: Haji Masagung.

Sudarko. 2003. Pakeliran Padat Pembentukan dan Penyebaran. Surakarta: Citra Etnika.

\section{Audio}

Hadiprayitno, Timbul. Lakon Kresna Duta. (Kaset), Fajar Record.

Hadiprayitno, Timbul. Rama Nitik. (Kaset), Fajar Record.

Sugito, Hadi. Durno Picis. (Kaset), Fajar Record. Sugito, Hadi. Anoman Lair. (Kaset), Fajar Record. Suparman. Sadewa Ratu. (Kaset), Kusuma Record. Suparman. Pramusinto Takon Bapa. (Kaset), Dablia Record. 